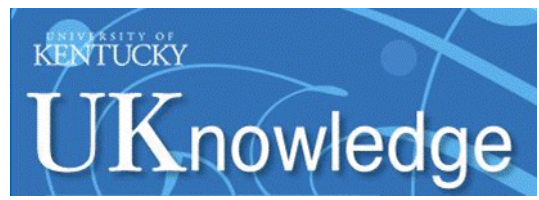

University of Kentucky

UKnowledge

Educational Policy Studies and Evaluation

Faculty Publications

Educational Policy Studies and Evaluation

$1-2020$

\title{
The Pragmatist's Call to Democratic Activism in Higher Education
}

Eric Thomas Weber

University of Kentucky, eric.t.weber@uky.edu

Follow this and additional works at: https://uknowledge.uky.edu/epe_facpub

Part of the Higher Education Commons, and the Social and Philosophical Foundations of Education

Commons

Right click to open a feedback form in a new tab to let us know how this document benefits you.

\section{Repository Citation}

Weber, Eric Thomas, "The Pragmatist's Call to Democratic Activism in Higher Education" (2020). Educational Policy Studies and Evaluation Faculty Publications. 17.

https://uknowledge.uky.edu/epe_facpub/17

This Article is brought to you for free and open access by the Educational Policy Studies and Evaluation at UKnowledge. It has been accepted for inclusion in Educational Policy Studies and Evaluation Faculty Publications by an authorized administrator of UKnowledge. For more information, please contact UKnowledge@lsv.uky.edu. 


\section{The Pragmatist's Call to Democratic Activism in Higher Education}

Digital Object Identifier (DOI)

https://doi.org/10.5840/eip2020211/23

\section{Notes/Citation Information}

Published in Essays in Philosophy, v. 21, issue 1/2.

(C) 2020 Weber

his open access article is distributed under a Creative Commons Attribution 4.0 License

(https://creativecommons.org/licenses/by/4.0/). 
Essays in Philosophy

ISSN 1526-0569 | Essays in Philosophy is published by the Philosophy Documentation Center, in cooperation with Pacific University

Volume 21, Issue 1-2 (2020)

The Pragmatist's Call to Democratic Activism in Higher Education

Eric Thomas Weber

The University of Kentucky

\begin{abstract}
This essay defends the Pragmatist's call to activism in higher education, understanding it as a necessary development of good democratic inquiry. Some criticisms of activism have merit, but I distinguish crass or uncritical activism from judicious activism. I then argue that judicious activism in higher education and in philosophy is not only defensible, but both called for implicitly in the task of democratic education as well as an aspect of what John Dewey has articulated as the supreme intellectual obligation, namely to ensure that inquiry is put to use for the benefit of life.
\end{abstract}

Essays Philos (2020)21:29-45 | DOI: 10.5840/eip2020211/23

Correspondence: eric.t.weber@uky.edu 
Education without social action is a one-sided value because it has no true power potential. Social action without education is a weak expression of pure energy. Deeds uninformed by educated thought can take false directions. When we go into action and confront our adversaries, we must be as armed with knowledge as they. Our policies should have the strength of deep analysis beneath them to be able to challenge the clever sophistries of our opponents. $\sim$ Martin Luther King, Jr.

When we think of activism in higher education, such as in images from the 1960's or in recent conflicts about controversial speakers invited to or disinvited from college campuses, ${ }^{2}$ student leaders come to mind first and foremost. Critics of higher education today see college as frivolous, wasteful, or irrelevant, or, ironically, as troublingly activist, with a liberal agenda. ${ }^{3}$ Students are considered young and foolish, ${ }^{4}$ but it is the professors who are the problem, some critics have argued. ${ }^{5}$ In contrast with faculty members, administrators are more commonly thought of as company men and women. Secure, tenured professors, a privileged few becoming scarcer every year, ${ }^{6}$ are afforded the protections of academic freedom, and some use these protections for activism. There are ways of being

\footnotetext{
${ }^{1}$ Martin Luther King, Jr., Where Do We Go from Here (Boston: Beacon Press, 1968 / 2010), 164. I am grateful to Greg Moses for calling my attention to this passage.

${ }^{2}$ Evan Gerstmann, "Why This Is No Time for College Students to Turn Their Backs on Free Speech," Forbes.com, February 5, 2019, URL: https://www.forbes.com/sites/evangerstmann/2019/02/05/whythis-is-no-time-for-college-students-to-turn-their-backs-on-free-speech/
}

${ }^{3}$ Neil Gross, Why Are Professors Liberal and Why Do Conservatives Care? (Cambridge, MA: Harvard University Press, 2013).

${ }^{4}$ Eric Thomas Weber, “Students' Flag Request Was 'Emotional' but Courageous,” The Clarion Ledger (Jackson, MS), October 30, 2015, 2C, https://www.clarionledger.com/story/opinion/ columnists/2015/10/30/students-flag-request-emotional-but-courageous/74885008/.

${ }^{5}$ See especially David Horowitz, The Professors: The 101 Most Dangerous Academics in America (Washington, D.C.: Regnery Publishing, Inc., 2006). See also David Horowitz and Jacob Laksin, One-Party Classroom: How Radical Professors at America's Top Colleges Indoctrinate Students and Undermine Our Democracy (New York: Crown Forum Publishing, 2009); Bryan Caplan, The Case Against Education: Why the Education System Is a Waste of Time and Money (Princeton, N.J.: Princeton University Press, 2019); Jason Brennan and Phillip Magness, Cracks in the Ivory Tower: The Moral Mess of Higher Education (New York: Oxford University Press, 2019).

${ }^{6}$ Colleen Flaherty, “A Non-Tenure-Track Profession?” InsideHigherEd.com, October 12, 2018, URL: https://www.insidehighered.com/news/2018/10/12/about-three-quarters-all-faculty-positions-are-tenuretrack-according-new-aaup. According to Flaherty and an analysis by the American Association of University Professors based on 2016 data from the Integrated Postsecondary Education Data System, "About three-quarters of all faculty positions are off the tenure track." 
an activist that clash with the purposes and expectations of education and scholarship, to be sure, but there are ways that do not. In this paper, I will clarify and defend what I believe to be ways and methods of engaging in activism that are not only acceptable but that are both necessary for good democratic education and aspects of what John Dewey called the supreme intellectual obligation. I will refer to the two contrasting forms of activism I have in mind as uncritical activism versus judicious activism. An extension of this project could focus on the examination of particular cases of activism, to defend or criticize actions or decisions of faculty members, students, administrators, and relevant stakeholders. My aim in this paper is to address the broader question of whether or not scholars should see themselves as best when sequestered in their ivory towers or engaged in dialogue with the wider public about matters that demand public attention or redress. In what follows, I will begin with what I take democratic activism to be in higher education, explaining how and why an obligation to it emerges as a result of democratic inquiry. Next, I will explain why some people are worried about activism in colleges and schools, as well as in the discipline of philosophy. Then, I will explain the sort and forms of what I take to be judicious activism and how it is both acceptable in education as well as necessary for the kind of education that democracy requires. Finally, I will explain what Dewey called "The Supreme Intellectual Obligation,"; as well as the consequent call to activism that philosophers and our colleagues in other fields should feel in higher education.

\section{Democratic activism in higher education \& its intellectual roots}

Randy Martin's essay, "Academic Activism," opens with two definitions drawn from the Oxford English Dictionary (OED), revealing a conceptual tension between what is considered academic and what is called active. ${ }^{8}$ He notes that "Academic" is defined in the OED as "Not leading to a decision; unpractical; theoretical, formal, or conventional." "Active," by contrast, is defined as "Opposed to contemplative or speculative: Given to outward action rather than inward contemplation or speculation; practical; es. With 'life."' The divide we see here is akin to the clash that arises occasionally between the pure or basic

\footnotetext{
7 John Dewey, "The Supreme Intellectual Obligation," Science Education 18 (February 1934): 1-4. Republished in The Collected Works of John Dewey: The Later Works, Volume 9, edited by Jo Ann Boydston (Carbondale, IL: Southern Illinois University Press, 1934 / 2008), 96-102. The essay was originally an address that Dewey delivered before the American Association for the Advancement of Science.

${ }^{8}$ Randy Martin, “Academic Activism," Publications of the Modern Language Association of America (PMLA) 124, Issue 3 (May, 2009): 838-846.

${ }^{9}$ Ibid., 838.
} 
scientist and the engineer. At the same time, there is no contradiction in pursuing a Ph.D. in engineering. Rather, there are degrees of emphasis on what is theoretical and what is practical. The ideal is very often useful for practical work, and theoretical work untethered to real life can lack meaningfulness, if no conceivable relation can be found between speculation and even a modest potential relation to life or experience. Extremities of thought about the difference between being active versus being academic help us to understand the kinds of motivations that arise when critics want colleges and universities to be free from ties to practical life. A kind of piety is at work in the belief that what is academic should not be dirtied by practicalities. At the same time, the tradition of philosophical Pragmatism made the case that the very meaning of our concepts is to be understood in terms of the conceivable practical consequences that they bare for life. And thus, when scholars engage in inquiry, if it is meaningful, it will bare consequences for living and thus obligations on the part of those who inquire to share what they know and to advocate for what is right.

In light of background tensions between being active and being academic, and in recognition of what it means to engage in meaningful inquiry, a need then arises for understanding what it means to engage in democratic inquiry in higher education. For something to be democratic, I mean that it aims to empower people to be self-directing and better off for it, while respecting the good both of the whole and of minorities in the community. When I refer to activism in higher education, I mean a kind of publicly communicative leadership or advocacy for a cause, whether for change, in thought or action, or for the preservation of what is presently more just than a proposed alternative.

The conceptual tension that Martin presents is felt and raised often in connection with the philosophical tradition known as Pragmatism, as if it were untheoretical as an outlook. Pragmatists typically care about how and why ideas matter for life, what conceivable consequences would come from one belief in contrast with another, or one conceptualization rather than an alternative one. Pragmatists often must answer critics who believe that to be pragmatic is to be uncritical, to set aside philosophy. In fact, Charles Peirce's founding insight for the Pragmatist tradition was inspired by science, in which the meaning of a hypothesis is to be understood in terms of the conceivable consequences of its being true. If a hypothesis implies no conceivable difference for scientific testing, it is essentially meaningless, representing a difference that makes no difference.

It is worth noting that the pragmatic theory of meaning is reminiscent of the Logical Positivist tradition. That tradition is known for claiming that a statement is meaning- 
ful only if it is empirically verifiable. ${ }^{10}$ The problem for Logical Positivists is that their central claim itself is not empirically verifiable, and thus does not hold up to its own expectations for meaningfulness. The Pragmatists avoid this mistake, since there are conceivable practical consequences to adopting the Pragmatist theory of meaning. For one thing, it means that some hypotheses are essentially meaningless or not scientifically verifiable. As a consequence, Pragmatists generally abandon questions for which there are no conceivable practical consequences for life or belief, focusing on those matters for which there are conceivable consequences. This outlook also helps to explain why Pragmatists are generally inclined towards public philosophy or activism. In addition, it offers an initial way of responding to the $a$ priori reasoning that says that by definition philosophy is or academics are impractical. It simply need not be so, even if everyday language includes a usage of "merely academic" that refers to what is impractical. It is an association that ought to be resisted, except for the good cause of supporting matters for which some people are unimaginative or unwilling to entertain theories or thinking that is only conceivably relevant to life. I have in mind here especially the arts, but even theoretical sciences are sometimes dismissed as unimportant. In Einstein's day, his theories were only conceivably meaningful for experimentation in real life, but today the Large Hadron Collider has enabled the testing and confirmation of his theories." Thus, the fact that a difference might only be conceivable does not mean it will always only make a conceptual difference. Things change. In addition, ideas and ideals may not map onto the real world exactly, as in the geometric idea of a point, which has no extension. Nevertheless, ideas and ideals can direct human action for better or worse results, such as in the idea of a perfect circle, an infinite set of points, each with no extension, equidistant from a center. That idea may be impossible to map exactly onto the world, yet it can teach us how to draw or create more perfect circles than we would have without the idea. Here we find a way of bridging the gap between the theoretical or abstract and the practical. Perfect circles, like ideas of perfect societies, may be impossible to create in real life, yet can be useful for our efforts to engineer more circular objects or to design more just social policies.

An example can help to drive home the point here. Historically, doctors were understood to be authorities over patients and some people were not treated as autonomous moral beings who should have the right to make their own medical decisions. Today, we have practices and policies in place to protect patients' autonomy, such that consent is

${ }^{10}$ A. J. Ayer, ed., Logical Positivism (New York: The Free Press, 1959), 10.

11 Don Lincoln, "Einstein's Theory Was Put to the Test. Guess What Happened," CNN.com, April 6, 2019, URL: https://www.cnn.com/2019/04/06/opinions/einstein-theory-tested-super-high-gravitylincoln/index.html. 
understood to be an essential element in medical treatment. Philosophers were involved in the development of some of the proposals and reports that have shaped the present medical and research-ethics landscape. Where people today are not consulted over matters that concern them, and where scholars are aware of such concerns, academics would be morally negligent if they were not to speak up in activist fashion, proclaiming concern for the humane treatment of people. This is an example of activism. The cause of respecting people's autonomy by means of securing consent may seem mundane today, yet the concept of consent remains only superficially understood and still an awkward ideal needing refinement for application. For instance, a patient with an $8^{\text {th }}$ grade education may sign a form that claims he or she has given consent to a medical procedure, but if knowledge and understanding of what he or she is consenting to are relevant to the giving of consent, as is generally thought, we have a significant gap between the expectations of consent and what might either be done or be possible in communicating the details of what a procedure will involve. A simple relevant case occurred in my life, and I have a Ph.D. in Philosophy. A doctor told me that my daughter would go into heart failure, and I, at the time, mistakenly thought the condition communicated to me was fatal. The heart seems essential as an organ and failure suggests that the essential organ in question would not function sufficiently for life. I was wrong, it turned out. Fortunately, no decisions that yielded lasting harm were made in my condition of ignorance, but the doctor in our case clearly assumed that we knew that heart failure is not fatal. So, the future of consent and of what will be needed with respect to advocacy and hence activism is complex and still in need of work, even with regard to a moral concept that has a longstanding, established place in medical practice.

The insights of philosophers like Charles Peirce and fellow Pragmatist John Dewey show us that in the very tasks of public, democratic inquiry, we find cause for attending to the consequences of ideas for life. When we note them and attend to them, I argue that there inevitably arise obligations as a result, since withholding information that could save someone's life would mean that a scholar bears responsibility for that loss of life. By the same token, scholars who understand and fail to speak up about matters such as vaccines and other life or death developments are complicit in the deaths that ensue from enabled, continuing ignorance.

\section{Why worry about activism in education and philosophy?}

Beyond the definitional concern that Randy Martin notes, two further worries can arise regarding the notion of activity and academics. One concern involves the need for objectivity in inquiry. The other has to do with worries about activism that is uncritical or crass. 
The question of objectivity in inquiry is deeply important in philosophy as in other fields and arenas in life. It is clear that in a court case, objectivity is necessary for justice, in the sense that if the judge has an interest, financial or otherwise, in the outcome of the case, the situation casts doubt on his or her judgment. Justice demands objectivity.12 Inquiry does too. People who have an interest in the tobacco industry or in selling gasoline are subject to motivations not to disclose their own internal findings if those suggest conclusions that would diminish profits. They might also with their considerable revenues be inclined to fund research that leads to the conclusion that their products bear important benefits or are less harmful or worrisome than objective study would show.

Some scholars have argued that when philosophers "apply ethics" they are really just presenting arguments that favor their own inclinations. ${ }^{13}$ In so doing, Gerald Gaus claims, they are therefore not really being philosophical, but just appear philosophical given their writing style and footnotes. Even worse, he charges, in applying ethics, philosophers "succeed in corrupting philosophy." ${ }^{14}$ I have argued against Gaus's claims in depth elsewhere. ${ }^{15}$ Gaus is critical of the Pragmatist's outlook, though he doesn't specifically name that tradition. He thinks attending to the practical consequences of ideas means that we choose to believe what we want to believe, thereby, rather than what the evidence really shows. Gaus translates this claim to the idea that any motivated reasoning is suspect. The problem I see is in Gaus's narrow conception of philosophy and his dismissal of motivated reasoning as being thereby of no value for serious objective inquiry. A parent may be able to articulate crucially important reasons why his or her child needs medical treatment and why the insurance company's denial of coverage is fallaciously argued, even if his or her attorney could more easily present the argument dispassionately. In other words, in attending so centrally to motivations for reasoning, Gaus commits the ad hominem fallacy. The fact of motivation for inquiry does not render one's judgment useless or unphilosophical. Making philosophical arguments is not the same as being a final Supreme Court arbiter. A child of a parent who dies of breast cancer may be highly motivated to find a cure, but interest and passion are not inherently biasing in a problematic way. Interests do not necessarily dictate

\footnotetext{
${ }^{12}$ Here it may be worth noting that by objectivity here, I do not mean a lack of emotion. For, as Aristotle rightly argued, I believe, sympathy can be essential for good judgment, which he refers to as "sympathetic judgment" in book XI of the Nicomachean Ethics. Sympathy can be what objectivity demands in a given case. Aristotle, Nicomachean Ethics (New York: Oxford World Classics, 2009), book XI.

${ }^{13}$ Gerald Gaus, “Should Philosophers ‘Apply Ethics’?” Think 3, no. 9 (Spring 2005): 63-68.

14 Ibid., 63.

${ }^{15}$ Eric Thomas Weber, “On Applying Ethics: Who’s Afraid of Plato's Cave?” Contemporary Pragmatism 7, Issue 2 (December 2010): 91-103.
} 
which approach to treating breast cancer will appear more likely to be successful. And, for a Pragmatist, the idea of studying matters for which no value for life is intelligible might well mean the gross misuse of public resources that could instead support work that benefits life. No one should give me a grant to count the number of discrete fibers in my rug, and fortunately no one will. But my absurd rug project, according to some philosophers, would be a more objective project than the personally motivated scientist studying breast cancer. So much the worse for that conception of objectivity, says the Pragmatist.

The more important critique of activism among scholars targets uncritical engagement undertaken under the guise of academic activity by association. When a person is granted a Ph.D., the world begins to refer to her or him with the honorific prefix, "Doctor." Similarly, "Professor" refers to someone taken to be an authority at least of some scope. It is very tempting, even unintentionally to use one's position to influence others about some matter over which one is not really educated.

I witnessed a science professor, who was the faculty advisor to a student organization with interest related to gun control, make flatly false claims in a public forum about gun safety policy and law concerning gun rights on campus. He acted as an activist promoting gun rights, which could in itself be an acceptable thing to do. In his case, however, he insisted that it was not against the law to have guns on campus at the University of Mississippi. He was in a faculty position, weighing in as if his statements were authoritative and as a professor advising students, and he was clearly wrong. I know this because of the arrests that were publicized involving Klansmen who were charged in 2015 with "possessing a firearm in a school zone", when they were found to have "guns in a truck parked on the University of Mississippi campus." ${ }^{16}$ The relevant professor's expertise was in a field entirely unconnected with gun rights. He failed to demonstrate confirmable expertise, references to sources from which one could learn more, and a level-headed attitude to discourse about a matter for which his role was advisory to students. This particular instance is an example of a broader pattern of behavior in which this professor wielded leadership influence over students, did so in a college setting and in a manner that was publicly communicative, and about matters of public policy relevant to the context of higher education and student safety.

One more example is worth noting here. In 2017, when Tommy Curry was a professor at Texas A\&M University, he received criticism from his university's President ${ }^{17}$ as well as

\footnotetext{
${ }^{16}$ Jeff Amy and Emily Wagster Pettus, "Feds: KKK Members Charged With Having Guns on Ole Miss Campus," The Clarion Ledger, October 27, 2015, URL: https://www.clarionledger.com/story/ news/2015/10/27/feds-kkk-members-charged-having-guns-ole-miss-campus/74670768/.
}

${ }^{17}$ Steve Kuhlmann, “Texas A\&M Philosophy Professor Criticized for Race Comments in 5-year-old 
over 80 death threats ${ }^{18}$ for an interview that he gave five years before on the Rod Redding podcast. He had been invited to talk about the ideas of racial violence that were raised in the movie Django Unchained. Jaime Foxx had made a joke on Saturday Night Live about the fantasy of killing slave owners and Redding asked Curry about it. Curry's comments were essentially communicating the fact that when black men and women talk about racial violence, even in cases of self-defense, it is taken as an affront. The American Conservative, an online publication that featured the writings of white supremacists such as Richard Spencer, misinterpreted Curry's work as a call for racial violence, a claim that was clearly undercut on Snopes.com ${ }^{19}$ as well as in The Chronicle of Higher Education. ${ }^{20}$ Unfortunately, Curry's university President at the time, Michael K. Young, failed to inquire into the white supremacist sources that motivated him to call Curry's comments "disturbing" and "in stark contrast to Aggie [(members of the Texas A\&M community)] core values - most notably those of respect and excellence, leadership and integrity - values that we hold true toward all of humanity." ${ }^{21}$ In this case, what we see is not an instance of a faculty member engaged in crass activism, but rather university administration taken in by politically biased, white supremacist organizations and voices, disregarding the expertise of the professor, who was hired precisely for the specialty he was exercising in the interview. Leadership that is publicly communicative, even when presented as if it aims to advance democratic values, can be misled or misleading, and can aim to rebuke wise public engagement. President Young's actions were at least negligent of the respect that was due to his faculty member. Most people would not call his actions activism, yet critics of the U.S. Supreme Court criticize judges as "activist" when they interpret the judges as advancing an agenda. If one could make a case for a pattern of Young's behavior that sought to make certain scholars feel unwelcome at the university, that pattern could

Podcast," The Eagle (Bryan, TX), May 11, 2017, https://www.theeagle.com/news/local/texas-a-mphilosophy-professor-criticized-for-race-comments-in/article_7b7cc350-9c18-538b-a5fe-7f5410144691. $\underline{\mathrm{html}}$.

${ }^{18}$ Weber, Eric Thomas, Anthony Cashio, and Tommy J. Curry, "The Public Philosopher and the Gadfly," Philosophy Bakes Bread, Episode 32, Transcribed by Drake Boling, WRFL Lexington 88.1 FM, Lexington, KY, July 11, 2017, https://www.philosophersinamerica.com/2017/08/05/036-ep32-thepublic-philosopher-and-the-gadfly/

${ }^{19}$ Bethania Palma, "Did a Texas A\&M Professor Advocate Killing White People?” Snopes.com, June 2, 2017, https://www.snopes.com/news/2017/06/02/texas-professor-white-people/.

${ }^{20}$ Steve Kolowich, “Tough Talk: Who's Left to Defend Tommy,” The Chronicle of Higher Education, July 26, 2017, https://www.chronicle.com/article/Who-s-Left-to-Defend-Tommy/240757.

${ }^{21}$ Colleen Flaherty, "Furor over Philosopher's Comments on Violence Against White People," InsideHigherEd.com, May 11, 2017, https://www.insidehighered.com/news/2017/05/11/furor-overtexas-am-philosophers-comments-violence-against-white-people. 
be labeled as a kind of crass or undemocratic activism. Young was negligent in failing to investigate matters carefully and with proper respect for Curry. This case demonstrates activism done right, on Curry's part, and wrongheaded criticism of activism, on the part of President Young.

My aim here is not to focus on examples, nor to propose particular sanctions for professors or administrators. After all, freedom of expression is quite important and sometimes valuable even when people are wrong or offensive. ${ }^{22}$ At the same time, troubling instances can help us to appreciate why some people might have cause to be concerned about activism. Professors and administrators in higher education are role models for some. They are afforded a significant amount of trust in their interactions with students. They are offered resources on which to draw for scholarship. Those fortunate to have the financial and job security of tenure, especially at state institutions, are members of a community that has a corresponding obligation to attend to the ways in which they wield their influence.

Philosopher John Lachs has argued that great teachers are the ones willing to offer themselves as examples to others. If we encourage others to act and to speak, professors should expect the same of ourselves. When we do so, however, we should put our best efforts into demonstrating the virtues of intelligent inquiry and communication. Lachs writes, How does one create or contribute to the development of human beings? By caring enough to offer oneself as a model students can imitate. That, in fact, is the heart of good teaching, and is not nearly as egomaniacal as it sounds. Good teachers don't have to be, and should not think they are, perfect in any aspect of life. No one is, and there is no reason to impose unreasonable demands on people. They just have to be good enough to be living embodiments of a standard worth attaining. ${ }^{23}$

Anyone can fall short of the reasonable call to action that Lachs presents here. I regret some of my own overstatements, for example..$^{24}$ That said, if we expect perfection, Lachs

\footnotetext{
${ }^{22}$ Shane Courtland offers a strong defense of offensive speech in his essay, "The Necessity of Offense," in Donald Alexander Downs and Chris W. Surprenant, The Value and Limits of Academic Speech: Philosophical, Political, and Legal Perspectives (London: Routledge Press, 2018), 155-166.

${ }^{23}$ John Lachs, "Teaching as a Calling," in A Community of Individuals (London: Routledge Press, 2003), 17.

${ }^{24}$ Eric Thomas Weber, “Trump's Popular Slogans Will Not Be Enough to Win Him the Primary Election: Weber," The Tehran Times, November 2, 2015, 1, http://ericthomasweber.org/trumps-slogansnot-enough-to-win/. I was amazed to find out how wrong I was about some of the things that Americans would find popular. The lesson has affected me deeply, but also has opened my eyes to some harsh
} 
notes, our expectations are too high. Thus, if professors are going to try to be models for others, in inquiry as in activism, we ought both to be patient with our occasional missteps yet dogged in our efforts to offer examples worth emulating. The next section will focus on what good, judicious activism can look like in higher education.

\section{What is judicious activism and why does democracy demand it in education?}

The converse of uncritical activism I call judicious activism. The term comes from the definition I proposed for desirable leadership in Democracy and Leadership. There, I called good leadership "judicious yet courageous guidance." ${ }^{25}$ Courage is an essential virtue of good leadership, I believe, because it is enabling. Knowing what is right and saying nothing as the community follows foolish leaders means that knowledge or wisdom, unaccompanied by courage, does little good. Activism is conceptually enabled in its engagement. The question is whether or not it is wise, or as I would say, judicious. For Plato, Socrates in the Republic chiefly touts the centrality of wisdom for leadership. But, even there wisdom must be accompanied by further virtues, including courage, moderation, and justice. In Democracy and Leadership, I propose that we use the word judicious to capture the three virtues that accompany courage, namely wisdom, moderation, and justice. It is in this context that I argue that judicious activism is both defensible in higher education and necessary for democracy. The activism I have in mind should be guided by wisdom, moderation, and justice.

What does it mean for activism in higher education to be guided by wisdom? For one thing, it should either be related to matters connected to one's intellectual expertise or it should be informed by the careful inquiry that academia should strive to foster in students. In "Philosophy and Public Policy," Sidney Hook presented four ideas about what philosophers have to contribute to public policy debates. Elsewhere, I have added three further contributions that philosophers have to offer. ${ }^{26}$ The first, Hook points out, is the kind of careful attention to the facts and best available information that any intelligent, careful person and community member should strive to know. Second, philosophers can be clarifying, offering methodological sophistication that "sharpens the issues at point

realities.

${ }^{25}$ Eric Thomas Weber, Democracy and Leadership: On Pragmatism and Virtue (Lanham, MD:

Lexington Books, 2013), 18.

${ }^{26}$ Eric Thomas Weber, “On Applying Ethics: Who’s Afraid of Plato's Cave?” Contemporary Pragmatism 7, Issue 2 (December 2010), 91-103. 
in public controversy." ${ }^{27}$ Third, philosophers can disentangle different kinds of claims for analysis. Fourth, Hook explains, philosophers can "make explicit the ethical issues behind conflicting public policies and to relate them to the kind of society in which we want to live and to the kind of men and women we wish to see nurtured in such a society." ${ }_{28}$ Fifth, I add that in our analysis of claims and assumptions that different people make in policy debates, philosophers can identify matters of what John Rawls has called "overlapping consensus," common ground despite other differences. Sixth, philosophers could contribute substantively to argumentation about agenda setting, such as in the ways in which utilitarian thinking can argue for which sets of matters might make the biggest positive difference for the largest number of people. Deontologists have been useful in thinking about fundamental rights and obligations. Virtue ethicists have pointed to important matters for habit formation and character development that could guide educational agenda setting, if only it were wisely led. Seventh, philosophers are exceptionally good at creative rethinking, reconceptualization, a kind of reframing of ideas when old or outmoded principles no longer suffice for present problems. My point in revisiting such lists is first of all that philosophers and other scholars have much to offer and that there are ways in which they can contribute to enhancing the wisdom of public discourse. These examples so far of ways of contributing point to some of the specialties that philosophers have to offer for the sake of wisdom, but they also point to contributions with respect to moderation.

It is worth recalling that in the Republic, Plato's Socrates argues that moderation is an essential virtue for the good city. Without it, fractures would grow more extreme and the city would be torn in two, with each part at war with the other. Moderation achieved with excellence yields unity. Philosophers and other scholars can help to humanize people who are caricatured. We can look to underlying assumptions across political divides to note what is valued in common even in disagreements as heated as the topic of abortion. ${ }^{29}$ Philosophers also can contribute to thinking about standards of knowledge and evidence, considering sources and claims that people propose. Sometimes people might be wrong about science, such as in climate change denial, but right about the human worries people have about loss of jobs and the call for addressing out-of-work families' needs.

As Hook noted, philosophers can attend to ethics and justice. The principle of academic charity is too infrequently invoked in the public sphere. Trying to understand where

\footnotetext{
${ }^{27}$ Sidney Hook, "Philosophy and Public Policy," The Journal of Philosophy 67, Issue 14 (1970): 461$470,467$.

${ }^{28}$ Ibid.

${ }^{29}$ Bertha Alvarez Manninen, Pro-Life, Pro-Choice: Shared Values in the Abortion Debate (Nashville, TN: Vanderbilt University Press, 2014).
} 
someone is coming from is a skill that most good teachers learn early. At the same time, philosophers can help to raise the bar about matters that involve the inhumane treatment of others.

Judicious activism in general is informed by the facts and embodied in action taken to advance the common good, through measures that are themselves moral. As such, philosophers and other scholars could inform activist communications in ways that call attention to crucially important values and social goods. They can fight to make schools, colleges, and universities more inclusive, inviting, and welcoming of people who have traditionally been excluded. Sometimes that means that scholars need to work on each others' attitudes about disability and underrepresented scholarly traditions. After all, while the proportion of women studying philosophy has risen significantly over the last 30 years, the percentage of African American professional philosophers in the United States is still around $2 \%{ }^{30}$ Disability is still underrepresented and researched in the academy, and countless concerns could be addressed humanely, with care, compassion, and rigor, yet communicated accessibly in public engagement. These tasks are hard, and so the indifferent or those inexperienced in employing accessible communication at times belittle those who venture into dialogue with the public. Cultures can change, however, even if slowly and over a long period of time. Scholars can contribute wisely, with informed, careful argumentation and the pursuit of the common good and justice in mind. While judicious activism should be considered acceptable, it is also in some ways called for in the very act of democratic education, especially in public institutions, or in any of our higher educational institutions that are granted the benefits of not-for-profit status. These institutions all are expected to advance the common good. And, such institutions that accept any kind of federal dollars in the United States are expected not to discriminate. But, can black students at the University of Mississippi expect a quality education will be made available to them with equal respect as others receive if the Confederate Battle Flag is featured in the canton of the state flag that flew on campus? A Louisiana parish was convinced that a black death row inmate could not expect a fair trial in a courthouse over which the Confederate Battle Flag was flying. ${ }^{31}$

\footnotetext{
${ }^{30}$ The American Philosophical Association, "Demographic Statistics on the APA Membership, FY2016 to FY2018," URL: https://cdn.ymaws.com/www.apaonline.org/resource/resmgr/data_on_profession/ fy2018-demographic statistic.pdf. Of 8,266 members of the APA, 127 were Black/African-American in 2018 , or $1.53 \%$.

${ }^{31}$ John Simerman, "Confederate Flag Plays Major Role in Shreveport Death Penalty Challenge," The Times-Picayune and The New Orleans Advocate on NOLA.com, May 10, 2011, URL: https://www.nola. com/news/crime police/article 94d86fff-c5cb-5e33-b178-5bf4b4e1bacc.html.
} 
By the same token, how can a student feel comfortable taking a class or meeting with faculty who will treat them fairly when they have to meet them in buildings named after white supremacists who advocated explicitly for lynching all "negroes" for the sake of white supremacy, as in Vardaman Hall, named after just such a Mississippi Governor? ${ }^{32}$ Teaching in a democratic society, in which all students are supposed to be respected as pupils and scholars cannot mean enabling some students to dehumanize their peers. When a male student shouts down a female student, professors have a duty to address the behavior in question. As the title of Howard Zinn's autobiography puts it, You Can't Be Neutral on a Moving Train..$^{33}$ To strive to educate all students to the best of your ability brings with it the task of empowerment of all of them, empowerment of all the people, which is precisely part of what democracy demands, especially democratic education. Thus, the democratic educator should be at least minimally engaged in a kind of democratic activism that his or her job requires.

Countless references could be offered for examples of publicly engaged scholars demonstrating judicious activism, supported by wisdom, and pursuing moderation and justice. Instead of offering a laundry list, I have focused here on the principle and the call for such action. At the same time, John Dewey argued for a more robust kind of expectation in his powerful speech delivered before the American Association for the Advancement of Science in 1934, "The Supreme Intellectual Obligation." I will turn to and conclude with Dewey's call now.

\section{The Supreme Intellectual Obligation}

Elsewhere, ${ }^{34}$ I have written about public philosophy drawing on Dewey's address before the American Association for the Advancement of Science, "The Supreme Intellectual Obligation." For my present purposes, it is worth revisiting that essay to highlight the extent to which the publicly engaged philosophy that Dewey would call for could be understood to be a kind of activism.

In that essay, Dewey argues essentially that the chief intellectual obligation is to ensure that inquiry be put to use for the benefit of humanity. I argued previously about the

\footnotetext{
32 Adam Ganucheau, "Ole Miss Will Rename Vardaman Hall, Place Plaques to Put 'Past Into Context'," Mississippi Today, July 6, 2017, URL: https://mississippitoday.org/2017/07/06/ole-miss-will-renamevardaman-hall-contexualize-other-sites/.

${ }^{33}$ Howard Zinn, You Can't Be Neutral on a Moving Train (New York: Beacon Press, 2002).

${ }^{34}$ Eric Thomas Weber, "Lessons from America’s Public Philosopher," The Journal of Speculative Philosophy 29, Issue 1 (2015): 118-135.
} 
implications of such a view, concerning the consequent need for publicly engaged philosophical scholarship. Advocates for public philosophy sometimes argue that it is essential for scholars to avoid jargon and to be accessible to the public. It is true sometimes that such changes in vocabulary, language, and audience are important, but in fact Dewey in his essay notes that much great scholarship may well be necessary and be well pursued among specialists and technicians who will use impenetrable jargon, at least for the rest of us. That said, the insights that they develop leave people suffering from whatever they could have informed for the public benefit if they are not put to use for humanity. In other words, it may be that some of the chemistry of water supplies and agriculture will be complicated and above the heads of most Americans, yet the insights about how to promote health and clean drinking water ought to be brought to bear on the development of new water systems and the improvement of failing ones. ${ }^{35}$ At the same time, chemists are not necessarily trained in public advocacy. Therefore, philosophers and other scholars whom Dewey famously called "liaison officers" are needed to enable translation and to put the insights of the arts and sciences to work for the public benefit. ${ }^{36}$

In his essay, Dewey argued that while new insights and technological developments often bring new problems, part of the supreme intellectual obligation is the call constantly to be working on applying inquiry to the alleviation of the new problems that past inquiries and advances have caused. Inquiry is never over or done, as a result. In addition to this consequence, Dewey noted a crucially important aspect of the supreme intellectual obligation, which is that if the masses, the wider population, are poorly educated about the sciences and civic arts, then they may well be unable to take advantage of the benefits of new insights and advances. This then means that the supreme intellectual obligation necessitates advocacy, a kind of activism, for ensuring that all people have the tools as well as the habits of mind and intellectual attitudes necessary for appreciating wisdom and putting it to use. That is no small task, and far too often, the elite scholar in the ivory tower thinks that the Plebe in the streets is a distraction and a nuisance in the way of his or her work, clogging up traffic and valuable time. Such scholars, furthermore, often inexperienced in speaking to persons with less than some college education feel that they

\footnotetext{
${ }^{35}$ Here, of course, I have in mind conditions of the water in Flint, Michigan. See Emma Winowiecki, "Does Flint Have Clean Water? Yes, but It's Complicated," Michigan Radio, Michigan's NPR News Leader (michiganradio.org), August 21, 2019, URL: https://www.michiganradio.org/post/does-flinthave-clean-water-yes-it-s-complicated.

${ }^{36}$ See for example Danielle Lake and Paul Thompson, "Philosopher-as-Liaison? Lessons from Sustainable Knowledge and American Philosophy," Dewey Studies 2, Issue 1 (2018): 10-41, URL: http://www.johndeweysociety.org/dewey-studies/files/2018/09/03 DS 2.1.pdf.
} 
are debasing themselves to translate their research into digestible chicken nuggets, from which all nutrition has been extracted in processing.

Two things are important to note in Dewey's argument. The first is that not all scholars are called to be public philosophers or public intellectuals. There certainly are plenty who would do best just sequestering themselves and focusing on the work to which they can valuably contribute. If they are teachers, where called for, one hopes that their abilities to talk with non-specialists would be refined, but nevertheless, the point is that not everyone must engage the wider public beyond our classrooms in higher education. The second consequence of Dewey's argument is that, if he's right, intellectuals all should see as part of their task advocacy for a strong and high quality public education, education for all, such that people can maximally benefit from the greatest wisdom available.

There are those who deny the importance of education ${ }^{37}$ and of democracy. ${ }^{38}$ The authors of such arguments may not agree about the importance of advocating for education and for democracy, but Dewey elsewhere argued that even they contribute something important. In "Social Absolutism," Dewey writes that:

... it may be that the best thing which can happen to the ideal of democracy is to be put on the defensive. For then it will no longer remain a vague optimism, a weak benevolent aspiration, at the mercy of favorable circumstances. It may become a compact, aggressive and realistic intelligence directing circumstance. ${ }^{39}$

Even if there is need for room for people to disagree about activist causes, there can nevertheless be a demand for intellectuals to strive to put wisdom to use for the benefit of humanity. The existence of white supremacists doesn't change the fact that universities are meant to be open for and respectful of all - i.e. that they should be. Therein we find one of the strongest causes for activism in higher education. The very enterprise it is meant to advance requires that sources of insight be understood to come from anywhere. It calls for recognizing the powers in people and cultivating them to new heights. Dewey's cry demands both that we pursue knowledge with the aim of improving people's lives and that we ensure that findings obtained are made operable in life and policy, either by the specialists guided and overseen or through the hands of experts who can

\footnotetext{
${ }^{37}$ I have already mentioned Caplan, The Case Against Education.

38 Jason Brennan, Against Democracy (Princeton, NJ: Princeton University Press, 2017).

39 John Dewey, "Social Absolutism," in The Collected Works of John Dewey: The Middle Works, Volume 13, Edited by Jo Ann Boydston (Carbondale, IL: Southern Illinois University Press, 1983), 315-316.
} 
communicate accessibly with fellow citizens, both sharing insights and gaining them through exchanges with the public.

In this essay, I have emphasized higher education and philosophy as domains for potentially rich contributions to grow in judicious activism. The reasons for that are that higher education remains a special environment, in which individuals can still often pursue inquiries of their choosing or that are not only motivated by a particular corporation's interests. It is also a venue offering rich resources not presently available to everyone. And, some fortunate among us are granted the time, resources, and job security of tenure to think and write. We lucky few should feel a corresponding duty to make the richest use of that privilege possible for enhancing the lives of people whose tax dollars fund our public employee salaries and retirement accounts. Yes, we teach students, one of the obvious first lines of public engagement that scholars participate in through college courses. But we can see our work as the calling that it long has been considered. In higher education, the faculty are professors for a reason. We must profess a faith in the potential for democratic inquiry to advance the well-being of lives in and beyond our academies, and exhibit the courage to advocate for such progress as a part of our shared mission. 